\title{
Tillage and herbicide decrease soil biodiversity in olive orchards
}

\author{
Sara Sánchez-Moreno • Juan Castro • Elena Alonso-Prados • José Luis Alonso-Prados • \\ José María García-Baudín • Miguel Talavera • Víctor Hugo Durán-Zuazo
}

Accepted: 23 October 2014 / Published online: 19 November 2014

(C) INRA and Springer-Verlag France 2014

\begin{abstract}
Olive growing is a centenarian activity in Andalusia, Southern Spain. Andalusia holds the largest olive tree growing area in the world. In spite of the relevance of olive growing for the Mediterranean economy, the influence of soil biodiversity on olive crops has been seldom studied. We hypothesized that soil diversity must be well preserved because the Andalusian olive groves are low-input and no-till systems. Soil depth should also help to structure soil diversity. We tested the effect of site features and soil management on nematode diversity, soil properties and soil food webs. Site features included use, position, orientation, radiation, slope, altitude and regional scale. Soil management included tillage and herbicide use. Results show that at the large scale, nematode abundance and soil food web structure were reduced under the tree canopy affected by herbicides by 57.9 and $14.2 \%$, respectively, in comparison to areas not treated with herbicides. Nematode abundance decreased by $47.7 \%$, taxa richness by $12.4 \%$ and soil food web structure by $23.4 \%$ in areas where herbicides are applied, in comparison to surrounding oak woodlands. The absence of vegetation in bare soils impacted the lower levels of the soil food web, depleting bacterial and fungal-mediated decomposition channels. This depletion spread up in turn to microbivore nematodes and
\end{abstract}

S. Sánchez-Moreno • E. Alonso-Prados • J. L. Alonso-Prados • J. M. García-Baudín

Plant Protection Products Unit (DTEVPF), National Institute for Agricultural and Food Research and Technology, 28040 Madrid, Spain

J. Castro $\cdot$ M. Talavera

IFAPA Centro Camino de Purchil, Camino de Purchil s/n,

18004 Granada, Spain

V. H. Durán-Zuazo $(\bowtie)$

IFAPA Centro Las Torres-Tomejil, Ctra. Sevilla-Cazalla Km. 12,

41200 Alcalá del Río, Sevilla, Spain

e-mail: victorh.duran@juntadeandalucia.es nematodes in the upper level. We also found that nematode abundances decreased with soil depth on average by $73.2 \%$ from the top soil layer $(0-2 \mathrm{~cm})$ to the deepest one $(10$ $20 \mathrm{~cm}$ ), irrespectively of the tillage practice.

Keywords Cover crops $\cdot$ Herbicide $\cdot$ Nematode $\cdot$ Soil food web $\cdot$ Soil-management system

\section{Introduction}

Olive (Olea europaea L.) is probably one of the oldest Mediterranean crops, and it has been estimated that currently one third of European farmers are involved in olive growing (European Commission 2002). Spain holds the largest olivegrowing area in the world, with 2.6 million ha (MAGRAMA 2012), most of them situated in Andalusia (Southern Spain). However, the Andalusian olive farming is considered ecoinefficient, owing to the soil erosion and lixiviation of agrochemicals caused by the soil-management system used that relies on heavy soil disturbance (Gómez-Limón et al. 2012).

Sustainable practices such as cover cropping interweaved within the rain-fed tree crops, and several no-tillage systems have been proposed to overcome these problems (Durán et al. $2008,2009)$. The effects of these practices on physicochemical soil properties is well documented (Nieto et al. 2012; Durán et al. 2013), but their effects on soil biodiversity are seldom studied.

Despite of the relevance of olive growing in European agriculture and the focus given to maintenance of soil health and soil biodiversity (e.g. European Commission 2010), little information is available on olive grove soil biodiversity. Only some studies on microbial activity (Moreno et al. 2009; Montes-Borrego et al. 2013) and soil arthropods (Castro et al. 1996) are accessible. Among soil nematodes, studies are partial and scattered; García-Ruiz et al. (2009) related the 
nematode community structure to the organic or conventional management in South-Spain olive groves and Castillo et al. (2010) summarized the composition of the plant-parasitic nematode community in Andalusian olive groves.

Nematode assemblages have been used as bioindicators of soil ecological conditions in numerous agricultural systems due to their ecological characteristics: ubiquity, abundance and taxonomical and functional diversities. Nematode diversity responds rapidly to agricultural management (Yeates and Bongers 1999) and serves as bioindicator of various soil functions due to the numerous roles that nematodes play within the soil food web (Ferris et al. 2001; Ferris 2010).

The objectives of this study were to (1) assess soil nematode diversity, abundances and vertical distribution in olive orchards under different soil managements (cover crop, herbicide use and tillage regimes) and (2) study the relationships between site features and soil properties, soil food web condition and ecological indices based on nematode assemblages. To fulfil such objectives, a double approach, including the assessment of the nematode community response to several factors both in experimental and field conditions, was undertaken. Under this double approach, the two main sources of environmental variability were taken into account; first, results from a landscape-scale approach in which the effects of natural environmental variability were studied is reported, followed by a local-scale experiment in which man-induced variability through different management practices was included.

\section{Material and methods}

\subsection{Study areas and soil sampling}

\subsubsection{Study area 1}

This area was selected to develop the soil biodiversity study and was located in the basin of the Víboras River, Valdepeñas de Jaén (Andalusia, Spain) (Table 1). Three mature ( $>50$ years old) traditional rain-fed olive orchards of the cv. Picual in sloping lands with 70-100 trees per hectare and two dense shrubby oak (Quercus ilex L.) woodlands were selected to study the influence of the herbicide use and site features on soil nematode diversity and community structure. In olive groves, herbicides were applied on May under the canopy of the tree to control weeds (Fig. 1).

At each site, composite soil samples were taken from six randomly selected trees. In olive groves, three soil samples were taken in the area treated with herbicides (under the canopy) and three soil samples were taken in the non-treated area (outside the canopy), and samples from each area were composed into a single sample. In the oak woodlands, three soil cores were taken from each tree, under the canopy at $1.5 \mathrm{~m}$ from the tree trunk and composed into a single sample. Soil cores were taken with an auger soil sampler at $0-20-\mathrm{cm}$ depth. Three samplings were performed: i) March 2010 ( 2 months before the application of herbicides), ii) July 2010 ( 2 months after the application of the herbicides) and iii) October 2010 (5 months after the application of the herbicides). Therefore, 144 soil samples were taken (three olive groves $\times$ six trees $\times$ two areas $\times$ three samplings $)+($ two oak woods $\times$ six trees $\times$ three samplings). At the time of the first soil sampling, a GPS was used to record the position (latitude and longitude) and altitude of each sampling site.

\subsubsection{Study area 2}

This area was used to assess the vertical nematode distribution under different management systems and consisted of an experimental olive grove located in Arquillos (Andalusia, Spain) (Table 1). The plantation consisted of rain-fed olive trees of the cv. Picual with two to three trunks, planted in 1976 at a density of $70-100$ trees per hectares. The experimental design was a randomized complete block design of 35 elementary plots (five treatments per block $\times$ seven blocks); therefore, each treatment had seven repetitions. Each elementary plot was composed by 16 trees (four rows $\times$ four columns); the central section (four trees, in two rows $\times$ two columns) was sampled while the outer zones were considered buffer zones among treatments.

In February 2010, composite soil samples were gathered before tillage from two sampling points in the middle of each elementary plot. At each sampling point, $100 \times 50 \mathrm{~cm}$ trial pits were opened and soil cores were taken at depths of $0-2,2-5$, 5-10 and 10-20 cm. A modified soil sample ring kit (Eijkelkamp 07.53.SE model E), which includes a set of cylinders of 2, 3, 5 and $15 \mathrm{~cm}$ specifically manufactured for this purpose, was used. Soil cores from the same depth and from the two sampling points at the same elementary plot were combined into one single soil sample. Therefore, 140 soil samples were taken ( 5 treatments $\times 7$ blocks $\times 4$ depths). Soil samples were divided into two subsamples for nematode and physico-chemical analyses.

\subsection{Soil nematode analyses}

Fresh soil subsamples for nematode extraction were stored at $6-10{ }^{\circ} \mathrm{C}$ for no more than 1 week and then processed. Soil nematodes were extracted by a modification of the Baermann funnel method (Barker 1985). Nematodes were extracted after soaking fresh soil overnight from $400 \mathrm{~g}$ of fresh soil in the samples collected in the study area 1 and for $40 \mathrm{~g}$ of fresh soil in the samples collected in the study area 2 . In both cases, the total number of nematodes per sample was counted under the 
Table 1 Soil-management systems, location and site features of the study areas (S Spain)

\begin{tabular}{|c|c|c|c|c|c|c|c|c|c|}
\hline & & Location & $\begin{array}{l}\text { Surface } \\
\text { (ha) }\end{array}$ & $\begin{array}{l}\text { Altitude } \\
\text { (m a.s.l.) }\end{array}$ & Weed management & $\begin{array}{l}\text { Slope } \\
(\%)\end{array}$ & $\begin{array}{l}\text { Orientation } \\
\text { (degrees) }\end{array}$ & $\begin{array}{l}\% \text { North } \\
\text { facing }\end{array}$ & $\begin{array}{l}\text { Solar radiation } \\
\left(\mathrm{kWh} \mathrm{m}^{-2}\right)\end{array}$ \\
\hline \multirow[t]{5}{*}{ Study area 1} & Grove 1 & $\begin{array}{l}37^{\circ} 36^{\prime} 29^{\prime \prime} \mathrm{N} \\
03^{\circ} 49^{\prime} 17^{\prime \prime} \mathrm{W}\end{array}$ & 0.59 & 1045 & $\begin{array}{l}\text { Gly } 36 \%+\text { +Gly } 36 \%+\text { MCPA } \\
18 \%\end{array}$ & 23.1 & 61.4 & 73.71 & 1447 \\
\hline & Grove 2 & $\begin{array}{l}37^{\circ} 35^{\prime} 60^{\prime \prime} \mathrm{N} \\
03^{\circ} 49^{\prime} 45^{\prime \prime} \mathrm{W}\end{array}$ & 1.92 & 1131 & Gly $36 \%$ & 34.6 & 205.7 & 6.7 & 1476 \\
\hline & Grove 3 & $\begin{array}{l}37^{\circ} 36^{\prime} 39^{\prime \prime} \mathrm{N} \\
03^{\circ} 47^{\prime} 42^{\prime \prime} \mathrm{W}\end{array}$ & 5.9 & 992 & Gly $36 \%+$ mowing & 16.3 & 272.9 & 89.7 & 1330 \\
\hline & Oak woodland 1 & $\begin{array}{l}37^{\circ} 36^{\prime} 04^{\prime \prime} \mathrm{N} \\
03^{\circ} 49^{\prime} 46^{\prime \prime} \mathrm{W}\end{array}$ & - & 1168 & - & 49.4 & 213.5 & 8.3 & 1432 \\
\hline & Oak woodland 2 & $\begin{array}{l}37^{\circ} 37^{\prime} 51^{\prime \prime} \mathrm{N} \\
03^{\circ} 49^{\prime} 21^{\prime \prime} \mathrm{W}\end{array}$ & - & 1205 & - & 33.4 & 231.8 & 19.3 & 1550 \\
\hline \multirow[t]{5}{*}{ Study area 2} & $\mathrm{~T}$ & $\begin{array}{l}38^{\circ} 12^{\prime} 36^{\prime \prime} \mathrm{N} \\
03^{\circ} 23^{\prime} 01^{\prime \prime} \mathrm{W}\end{array}$ & 4.4 & 388 & Cultivator or disk harrow & 2.5 & 31 & - & 1807 \\
\hline & $\mathrm{NTH}$ & $\begin{array}{l}38^{\circ} 12^{\prime} 36^{\prime \prime} \mathrm{N} \\
03^{\circ} 23^{\prime} 01^{\prime \prime} \mathrm{W}\end{array}$ & 4.4 & 388 & Sim $90 \%$, Diu $80 \%+$ Gly $36 \%$ & 2.5 & 31 & - & 1807 \\
\hline & $\mathrm{CH}$ & $\begin{array}{lll}38^{\circ} & 12^{\prime} & 36^{\prime \prime} \mathrm{N} \\
03^{\circ} & 23^{\prime} & 01^{\prime \prime} \mathrm{W}\end{array}$ & 4.4 & 388 & Cover crop+Gly $36 \%$ & 2.5 & 31 & - & 1807 \\
\hline & $\mathrm{CM}$ & $\begin{array}{l}38^{\circ} 12^{\prime} 36^{\prime \prime} \mathrm{N} \\
03^{\circ} 23^{\prime} 01^{\prime \prime} \mathrm{W}\end{array}$ & 4.4 & 388 & Cover crop + mowing & 2.5 & 31 & - & 1807 \\
\hline & $\mathrm{CMD}$ & $\begin{array}{l}38^{\circ} 12^{\prime} 36^{\prime \prime} \mathrm{N} \\
03^{\circ} 23^{\prime} 01^{\prime \prime} \mathrm{W}\end{array}$ & 4.4 & 388 & $\begin{array}{l}\text { Cover crop }+ \text { mowing }+ \text { disk } \\
\text { harrow }\end{array}$ & 2.5 & 31 & - & 1807 \\
\hline
\end{tabular}

$T$ tillage, $N T H$ no tillage+herbicide, $C H$ cover crop+herbicide, $C M$ cover crop+mowing, $C M D$ cover crop+mowing + disk harrow, Diu diuron, $G l y$ glyphosate, MCPA 2-methyl-4-chlorophenoxyacetic acid, Sim simazine

binocular microscope and at least 100 nematodes were identified to genus or family level under the compound microscope, but different methodologies used impeded direct comparisons of results. Nematode abundances were expressed as total number of individuals per $100 \mathrm{~g}$ of dry soil.

Abundance of nematodes, taxa richness, Shannon Diversity Index (Shannon 1948), Maturity Index (Bongers 1990) and soil food web indices (Ferris et al. 2001) were calculated for each sample. The Maturity Index (Bongers 1990) weights the abundance of different nematode taxa belonging to five colonizer-persistent (cp) groups, a scale that classifies nematode families into five groups from cp-1 (enrichmentopportunistic nematodes) and cp-2 (nematodes with short life cycles, most microbial and plant feeders, relatively resistant to environmental perturbations) to $\mathrm{cp}-5$ (mostly predators and omnivores, with long life cycles and sensitive to environmental disturbance). Soil food web indices (Ferris et al. 2001) are based on nematode guilds (a combination of the cp groups and nematode trophic habits) and include the Basal Index, indicator of soil food web perturbed condition; the Enrichment Index, indicator of enrichment conditions dominated by fastgrowing bacterivore organisms; the Channel Index, indicator of the predominance of fungal-mediated organic matter decomposition and the Structure Index, indicator of structured soil food webs and enhanced ecological functions developed by higher trophic links. The Enrichment Index and Structure Index allow the diagnosis of the soil food web condition (Ferris et al. 2001).
Fig. 1 Olive plantations in sloping lands (a) and olive trees under conventional management showing the area under the canopy, treated with herbicides, and the area outside the canopy, covered with weeds (b)
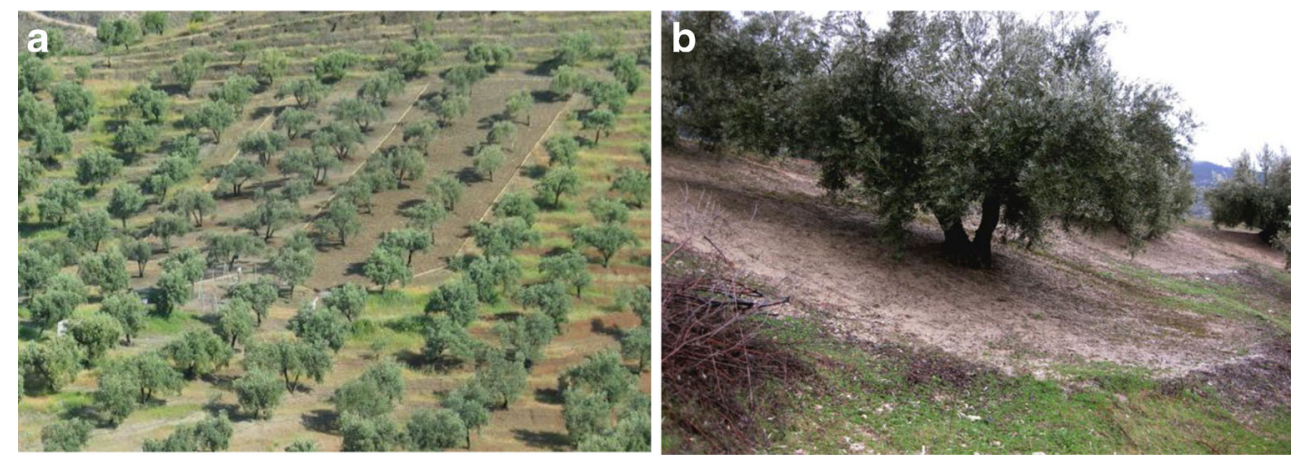


\subsection{Soil physico-chemical analyses}

Soil subsamples for physico-chemical analyses were air-dried, ground and sieved through a 2-mm sieve and used to analyze soil texture, $\mathrm{pH}$, soil organic carbon (SOC), total nitrogen $(\mathrm{N})$, available phosphorus $(\mathrm{P})$, potassium $(\mathrm{K})$, electrical conductivity, cation exchange capacity and soil moisture. All soil parameters were determined following the official analysis methods published by the Spanish Ministry of Agriculture (MAPA 1994).

\subsection{Statistical analyses}

ANOVAs were used to test the effect of sampling date on the nematode community within each habitat in the diversity study data set and to detect differences on the soil nematode community and soil properties in the study area 2 (data set 2 ). Factorial ANOVAs were used to assess the significance of the combined effect of tillage and weed control technique in data set 2 . Tukey tests were used as post hocs.

Canonical analyses were used to infer associations between site features, soil properties and the nematode community and the soil food web condition. Two analyses were performed. The first one was performed on data set 1 and related ecological indices to site features (latitude, longitude, altitude, slope, direction, percentage of north facing and estimated solar radiation) and the presence of native undisturbed soils. The second one was performed on data set 2 and related ecological indices to soil properties (clay, sand, silt, $\mathrm{pH}$, bulk density, SOC, total $\mathrm{N}, \mathrm{P}, \mathrm{K}$, cation exchange capacity, available water capacity), soil depth and soil management systems. In the resulting ordinations, variables scoring further from the graph centre present higher factor scores in the definition of the roots. To facilitate interpretation, independent variables were marked with arrows. All data were log-transformed before analysis.

\section{Results and discussion}

3.1 Biotic parameters in relation to soil-management systems

Forty-eight and 33 nematode taxa were found in the study areas 1 and 2, respectively. In area 1, 17 taxa were bacterial feeders, five fungivores, 17 herbivores, two omnivores and seven predators, while in area 2, 13 taxa were bacterivores, five fungivores, 11 herbivores, three predators and one was an omnivore. Most nematodes associated to olive orchards in both areas were bacterivores, often the most diverse trophic group in agricultural fields (Ferris et al. 2004), and herbivores, frequently abundant in perennial agricultural systems (Neher and Campbell 1994). Although nematodes can be important pests of olive trees (Castillo et al. 2010), no relevant abundances of pest taxa were found in any area.

In the study area 1 , nematode abundances were high in summer, although temporal dynamics were not strong and no significant differences on nematode abundances were found across sampling dates (Table 2). Nematode abundances often vary among seasons, since their metabolic activity and survival strategies largely depend on temperature and soil moisture. Such seasonal effects were almost absent within the olive orchards, probably because limited resources throughout the year do not allow populations' build up when environmental conditions are favourable.

Oak woodlands showed higher nematode richness, higher Maturity Index and lower Channel Index than the olive groves (Table 3), indicating more structured soil food webs than olive groves, and thus being a reservoir of soil diversity and presumably to their associated ecological services at the landscape level. Maintaining oak patches in olive-growing areas has been suggested as crucial for wildlife habitat restoration (Nekhay et al. 2009). In our study, we have shown that oak patches are also important for maintenance of soil biodiversity. The extremely high values of the Channel Index in olive groves are, however, not common in agricultural systems, indicating the prevalence of slow organic matter decomposition mediated by fungi, typical from mature forests.

Abundance of nematodes, taxa richness and the Structure Index were lowest within the area treated with herbicides, indicating a reduced soil food web complexity. Since herbicides are often harmless to soil fauna (Santos et al. 2011), effects of herbicide application on nematodes have to be mostly indirect, mediated by the effects on the diversity and the composition of the plant community (Parfitt et al. 2010). Soil food web condition in the study area 1 , indicated by the values of the Enrichment and the Structure Indices, ranged from degraded in the soil under the influence of herbicides to a structured condition in the oak woodlands (after Ferris et al. 2001), with intermediate values in the olive grove soils nontreated with herbicides.

Soil treatments also affected the nematode community in the study area 2 (Table 3). In the no-tillage+herbicide or bare soil treatment, the nematode abundance, nematode richness, Shannon Diversity Index and Channel, Enrichment and Structure indices were significantly lower than under any other treatment. Structure and the Channel Indices showed intermediate values in the cover+herbicide treatment and in the tillage and cover + mowing treatments, respectively (Table 3 ). Tillage and herbicides affected less biological indices than the combination of both; Channel Index only responded to the combination of tillage $\times$ herbicide, while nematode abundance responded to herbicide application but not to tillage. Enrichment and Channel indices are indicators of the prevalence of organic matter decomposition mediated by bacteria and fungi, respectively. Consequently, their low values in the bare soil 
Table 2 Values of nematode abundances, taxa richness, ecological indices, tardigrade abundance, and physico-chemical soil properties at different sampling dates and habitats in study area 1

\begin{tabular}{|c|c|c|c|c|c|c|}
\hline & \multicolumn{3}{|c|}{ Sampling date } & \multicolumn{3}{|l|}{ Habitat } \\
\hline & March & July & Oct. & $\mathrm{H}$ & $\mathrm{NH}$ & Oak \\
\hline \multirow[t]{2}{*}{ Tot. } & 317.20 & 657.08 & 340.71 & $251.60 \mathrm{a}$ & $596.86 \mathrm{~b}$ & $480.60 \mathrm{~b}$ \\
\hline & \pm 29.11 & \pm 105.83 & \pm 32.64 & \pm 40.65 & \pm 78.32 & \pm 79.77 \\
\hline \multirow[t]{2}{*}{ S } & $12.24 \mathrm{ab}$ & $12.00 \mathrm{a}$ & $13.18 \mathrm{~b}$ & $11.82 \mathrm{a}$ & $12.42 \mathrm{ab}$ & $13.50 \mathrm{~b}$ \\
\hline & \pm 0.37 & \pm 0.37 & \pm 0.35 & \pm 0.34 & \pm 0.29 & \pm 0.49 \\
\hline \multirow[t]{2}{*}{$\mathrm{H}^{\prime}$} & 1.85 & 1.87 & 1.97 & 1.87 & 1.90 & 1.93 \\
\hline & \pm 0.05 & \pm 0.04 & \pm 0.04 & \pm 0.05 & \pm 0.03 & \pm 0.05 \\
\hline \multirow[t]{2}{*}{ MI } & $1.83 \mathrm{a}$ & $1.80 \mathrm{a}$ & $1.45 \mathrm{~b}$ & $1.68 \mathrm{ab}$ & $1.60 \mathrm{a}$ & $1.87 \mathrm{~b}$ \\
\hline & \pm 0.06 & \pm 0.06 & \pm 0.07 & \pm 0.06 & \pm 0.07 & \pm 0.07 \\
\hline \multirow[t]{2}{*}{ EI } & 24.40 & 26.01 & 30.65 & 26.45 & 27.88 & 26.40 \\
\hline & \pm 1.80 & \pm 1.43 & \pm 2.24 & \pm 1.47 & \pm 1.78 & \pm 2.62 \\
\hline \multirow[t]{2}{*}{ SI } & 38.65 & 45.56 & 51.97 & $39.82 \mathrm{a}$ & $46.40 \mathrm{~b}$ & $51.98 \mathrm{~b}$ \\
\hline & \pm 3.56 & \pm 3.57 & \pm 3.11 & \pm 3.54 & \pm 3.22 & \pm 3.43 \\
\hline \multirow[t]{2}{*}{$\mathrm{CI}$} & 73.93 & 86.20 & 87.35 & $94.98 \mathrm{a}$ & $85.40 \mathrm{a}$ & $59.20 \mathrm{~b}$ \\
\hline & \pm 4.88 & \pm 3.61 & \pm 3.75 & \pm 1.56 & \pm 3.45 & \pm 6.30 \\
\hline \multirow[t]{2}{*}{ BI } & $48.94 \mathrm{a}$ & $43.42 \mathrm{ab}$ & $37.72 b$ & 47.03 & 42.46 & 39.43 \\
\hline & \pm 2.47 & \pm 2.38 & \pm 2.08 & \pm 2.26 & \pm 2.30 & \pm 2.57 \\
\hline \multirow[t]{2}{*}{ Tard. } & $6.06 \mathrm{a}$ & $30.73 a b$ & $37.83 b$ & $4.11 \mathrm{a}$ & $41.50 \mathrm{~b}$ & $29.87 b$ \\
\hline & \pm 1.92 & \pm 18.24 & \pm 15.35 & \pm 1.33 & \pm 19.01 & \pm 12.70 \\
\hline \multirow[t]{2}{*}{$\mathrm{pH}$} & 7.92 & 7.70 & 7.90 & 7.83 & 7.91 & 7.75 \\
\hline & \pm 0.05 & \pm 0.05 & \pm 0.04 & \pm 0.04 & \pm 0.05 & \pm 0.04 \\
\hline \multirow[t]{2}{*}{ SOC (\%) } & 3.22 & 3.21 & 3.24 & $1.89 \mathrm{a}$ & $1.72 \mathrm{a}$ & $7.56 \mathrm{~b}$ \\
\hline & \pm 0.49 & \pm 0.41 & \pm 0.42 & \pm 0.05 & \pm 0.16 & \pm 0.45 \\
\hline \multirow[t]{2}{*}{ N (\%) } & 0.25 & 0.27 & 0.25 & $0.15 \mathrm{a}$ & $0.18 \mathrm{a}$ & $0.54 \mathrm{~b}$ \\
\hline & \pm 0.03 & \pm 0.03 & \pm 0.03 & \pm 0.01 & \pm 0.02 & \pm 0.03 \\
\hline \multirow[t]{2}{*}{$\mathrm{EC}\left(\mu \mathrm{S} \mathrm{cm}{ }^{-1}\right)$} & $366.35 a$ & $256.34 \mathrm{~b}$ & $288.22 \mathrm{ab}$ & $330.76 \mathrm{ab}$ & $236.40 \mathrm{a}$ & $366.82 b$ \\
\hline & \pm 29.45 & \pm 31.60 & \pm 29.76 & \pm 34.45 & \pm 18.42 & \pm 38.13 \\
\hline \multirow[t]{2}{*}{$\mathrm{SM}\left(\mathrm{gH}_{2} \mathrm{O}\right.$ per g dry soil $)$} & $0.14 b$ & $0.02 \mathrm{a}$ & $0.15 b$ & $0.10 \mathrm{ab}$ & $0.08 \mathrm{a}$ & $0.14 \mathrm{~b}$ \\
\hline & \pm 0.01 & \pm 0.00 & \pm 0.01 & \pm 0.01 & \pm 0.01 & \pm 0.01 \\
\hline
\end{tabular}

Data are expressed as mean \pm standard error of the mean

Mean values for sampling dates or habitats in each row followed by the same letter do not differ significantly at $p<0.05$ according to Tukey tests

$H$ grove soils with herbicides (under the canopy), $N H$ non-treated grove soils (rows between tress), Oak oak woodlands, Tot. nematode abundance (number of nematodes $/ 100 \mathrm{~g}$ of dry soil), $S$ nematode taxa richness, $H^{\prime}$ Shannon Diversity Index, MI Maturity Index, EI Enrichment Index, SI Structure Index, $C I$ Channel Index, BI Basal Index, Tard. tardigrade abundance (number of tardigrades $/ \mathrm{kg}$ of dry soil), SOC soil organic carbon (\%), $N$ total nitrogen content, $E C$ electrical conductivity and $S M$ soil moisture

treatment may be due to depleted microbial functional diversity and reduced enzymatic activity, as previously reported by Moreno et al. (2009). These authors suggested that the presence of a vegetation cover was the main determinant of microbial performance and this effect may spread up to the next soil food web level, composed by enrichmentopportunistic bacterial-feeding and fungivore nematodes. Besides, the effects detected on soil food web complexity show that also nematodes at the upper levels of the soil food web, especially sensitive to environmental perturbation and chemical stress (Bongers and Bongers 1998), were affected by the bare soil treatment. Such changes on the soil biota may be due to the decrease on soil nutrients and increased soil compaction in bare soils (Moreno et al. 2009).

\subsection{Soil depth vs. nematode trophic groups}

Figure 2 shows that the abundances of nematode trophic groups were heavily affected by soil treatment and depth. Total nematode abundance and all trophic groups except predators were significantly affected by treatment and depth, while their interaction significantly affected total nematode abundance, bacterivores and herbivores ( $p<0.05$, data not shown). 
Table 3 Values of nematode abundances, taxa richness, ecological indices, tardigrade abundances and soil properties in different soil treatments in study area 2

\begin{tabular}{|c|c|c|c|c|c|c|c|c|}
\hline & $\mathrm{T}$ & NTH & $\mathrm{CH}$ & $\mathrm{CM}$ & CMD & Till. & Herb. & Till. $\times$ Herb. \\
\hline \multirow[t]{2}{*}{ Tot. } & $213.70 \mathrm{a}$ & $102.72 b$ & $497.50 \mathrm{a}$ & $591.57 \mathrm{a}$ & $242.77 \mathrm{a}$ & & $* *$ & $* *$ \\
\hline & \pm 22.52 & \pm 36.17 & \pm 75.22 & \pm 122.50 & \pm 37.25 & & & \\
\hline \multirow[t]{2}{*}{$\mathrm{S}$} & $8.19 \mathrm{a}$ & $4.65 b$ & $7.43 \mathrm{a}$ & $7.48 \mathrm{a}$ & $6.82 \mathrm{a}$ & $*$ & $* *$ & $* *$ \\
\hline & \pm 0.35 & \pm 0.60 & \pm 0.39 & \pm 0.35 & \pm 0.37 & & & \\
\hline \multirow[t]{2}{*}{$\mathrm{H}^{\prime}$} & $1.66 \mathrm{a}$ & $1.11 \mathrm{~b}$ & $1.36 \mathrm{a}$ & $1.52 \mathrm{a}$ & $1.52 \mathrm{a}$ & $* *$ & $* *$ & $* *$ \\
\hline & \pm 0.04 & \pm 0.12 & \pm 0.06 & \pm 0.05 & \pm 0.06 & & & \\
\hline \multirow[t]{2}{*}{ MI } & 2.19 & 2.25 & 2.19 & 2.24 & 2.22 & & & \\
\hline & \pm 0.05 & \pm 0.19 & \pm 0.05 & \pm 0.07 & \pm 0.05 & & & \\
\hline \multirow[t]{2}{*}{ EI } & $56.04 \mathrm{a}$ & $37.27 b$ & $50.78 \mathrm{a}$ & $51.38 \mathrm{a}$ & $51.00 \mathrm{a}$ & $*$ & $* *$ & $* *$ \\
\hline & \pm 2.12 & \pm 5.60 & \pm 2.50 & \pm 3.83 & \pm 2.14 & & & \\
\hline \multirow[t]{2}{*}{ SI } & $34.96 \mathrm{a}$ & $23.89 b$ & $24.36 \mathrm{ab}$ & $29.13 \mathrm{a}$ & $31.17 \mathrm{a}$ & $* *$ & $* *$ & $* *$ \\
\hline & \pm 3.45 & \pm 7.28 & \pm 3.68 & \pm 4.97 & \pm 4.46 & & & \\
\hline \multirow[t]{2}{*}{ CI } & $52.53 \mathrm{ab}$ & $47.63 b$ & $69.49 \mathrm{a}$ & $53.99 \mathrm{ab}$ & $69.60 \mathrm{a}$ & & & $* *$ \\
\hline & \pm 4.95 & \pm 8.40 & \pm 5.14 & \pm 6.23 & \pm 5.15 & & & \\
\hline \multirow[t]{2}{*}{ BI } & 34.20 & 40.71 & 41.49 & 36.02 & 38.62 & & & \\
\hline & \pm 1.66 & \pm 5.07 & \pm 2.31 & \pm 3.12 & \pm 2.43 & & & \\
\hline \multirow[t]{2}{*}{ Clay (\%) } & $23.23 \mathrm{a}$ & $15.22 \mathrm{~b}$ & $14.73 b$ & $18.00 \mathrm{~b}$ & $15.05 \mathrm{~b}$ & $*$ & $*$ & $* *$ \\
\hline & \pm 1.54 & \pm 1.97 & \pm 1.53 & \pm 2.19 & \pm 1.74 & & & \\
\hline \multirow[t]{2}{*}{ Sand (\%) } & $60.74 \mathrm{a}$ & $70.08 \mathrm{ab}$ & $69.83 \mathrm{ab}$ & $65.14 \mathrm{ab}$ & $70.58 b$ & & & $*$ \\
\hline & \pm 2.04 & \pm 2.69 & \pm 1.94 & \pm 2.60 & \pm 2.05 & & & \\
\hline \multirow[t]{2}{*}{ Silt (\%) } & 16.03 & 14.70 & 15.43 & 16.86 & 14.37 & & & \\
\hline & \pm 1.25 & \pm 1.00 & \pm 0.71 & \pm 0.82 & \pm 0.45 & & & \\
\hline \multirow[t]{2}{*}{$\mathrm{pH}$} & $7.03 a$ & $6.27 \mathrm{~b}$ & $6.20 \mathrm{~b}$ & $6.62 \mathrm{ab}$ & $6.36 \mathrm{~b}$ & $* *$ & $* *$ & $* *$ \\
\hline & \pm 0.11 & \pm 0.08 & \pm 0.13 & \pm 0.16 & \pm 0.12 & & & \\
\hline \multirow[t]{2}{*}{$\mathrm{BD}\left(\mathrm{g} \mathrm{cm}^{-3}\right)$} & $1.52 \mathrm{ab}$ & $1.66 \mathrm{a}$ & $1.64 \mathrm{a}$ & $1.56 \mathrm{ab}$ & $1.49 \mathrm{~b}$ & $* *$ & $* *$ & $* *$ \\
\hline & \pm 0.03 & \pm 0.03 & \pm 0.04 & \pm 0.05 & \pm 0.02 & & & \\
\hline \multirow[t]{2}{*}{ SOC (\%) } & $1.01 \mathrm{ab}$ & $0.63 \mathrm{a}$ & $1.02 \mathrm{ab}$ & $1.35 \mathrm{~b}$ & $1.29 \mathrm{~b}$ & $* *$ & $* *$ & $* *$ \\
\hline & \pm 0.07 & \pm 0.08 & \pm 0.20 & \pm 0.29 & \pm 0.06 & & & \\
\hline \multirow[t]{2}{*}{ N (\%) } & $0.10 \mathrm{ab}$ & $0.07 \mathrm{a}$ & $0.09 b$ & $0.14 b$ & $0.16 \mathrm{~b}$ & $* *$ & $* *$ & $* *$ \\
\hline & \pm 0.00 & \pm 0.00 & \pm 0.01 & \pm 0.03 & \pm 0.01 & & & \\
\hline \multirow[t]{2}{*}{$\mathrm{P}\left(\mathrm{mg} \mathrm{kg}^{-1}\right)$} & $4.34 \mathrm{a}$ & $14.03 \mathrm{~b}$ & $11.28 \mathrm{~b}$ & $7.07 \mathrm{a}$ & $5.04 \mathrm{a}$ & $* *$ & $* *$ & $* *$ \\
\hline & \pm 0.61 & \pm 2.35 & \pm 1.13 & \pm 0.91 & \pm 0.37 & & & \\
\hline \multirow[t]{2}{*}{$\mathrm{K}\left(\mathrm{mg} \mathrm{kg}^{-1}\right)$} & $79.24 \mathrm{a}$ & $52.33 \mathrm{a}$ & $110.21 b$ & $114.23 b$ & $86.24 \mathrm{ab}$ & & & $* *$ \\
\hline & \pm 6.11 & \pm 5.18 & \pm 7.44 & \pm 11.63 & \pm 5.88 & & & \\
\hline \multirow[t]{2}{*}{$\mathrm{CEC}\left(\mathrm{cmol} \mathrm{kg}^{-1}\right)$} & $6.93 \mathrm{ab}$ & $5.03 \mathrm{a}$ & $9.38 b$ & $10.69 \mathrm{~b}$ & $10.05 \mathrm{~b}$ & $*$ & $*$ & $* *$ \\
\hline & \pm 0.46 & \pm 0.24 & \pm 0.73 & \pm 1.24 & \pm 0.74 & & & \\
\hline
\end{tabular}

Data are expressed as mean \pm standard error of the mean. Mean values in each row followed by the same letter do not differ significantly at $p<0.05$ according to Tukey tests. The significance of the effects of tillage (Till), herbicide (Herb.) and their combination (Till. $\times$ Herb.) is indicated as $p<0.05(*)$ or $p<0.01(* *)$

$T$ tillage, $N T H$ no tillage +herbicide, $C H$ cover crop+herbicide, $C M$ cover crop+mowing, $C M D$ cover crop+mowing + disk harrow, Tot. nematode abundance (number of nematodes $100 \mathrm{~g}$ of dry soil), $S$ nematode taxa richness, $H^{\prime}$ Shannon Diversity Index, MI Maturity Index, EI Enrichment Index, $S I$ Structure Index, $C I$ Channel Index, $B I$ Basal Index, $B D$ bulk density, SOC soil organic carbon, $C E C$ cation exchange capacity

In the tillage, cover+herbicide and cover+mowing treatments, total nematode abundance was significantly reduced at the deepest layer, due to the reduction in the abundance of bacterivores, fungivores and herbivores. In the no-tillage+ herbicide and cover+mowing + disk treatments, the effect of depth was not significant (Fig. 2). Predatory nematode abundances were low and presented high deviations, so no effects of depth was found in any treatment for the predator trophic group. The soil food web in the study area 2 either was degraded (soils 2-20-cm depth) or disturbed (all treatments 

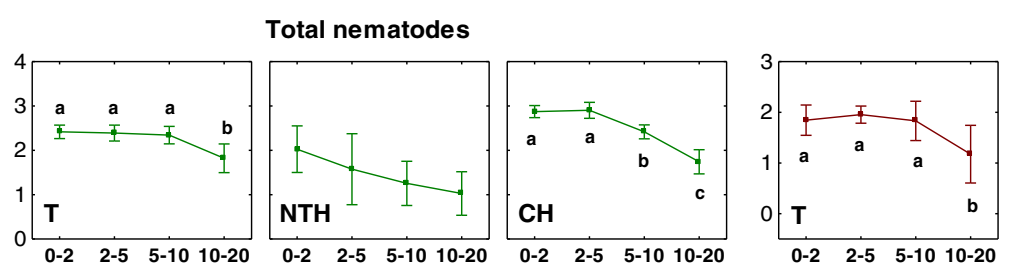

Bacterivores
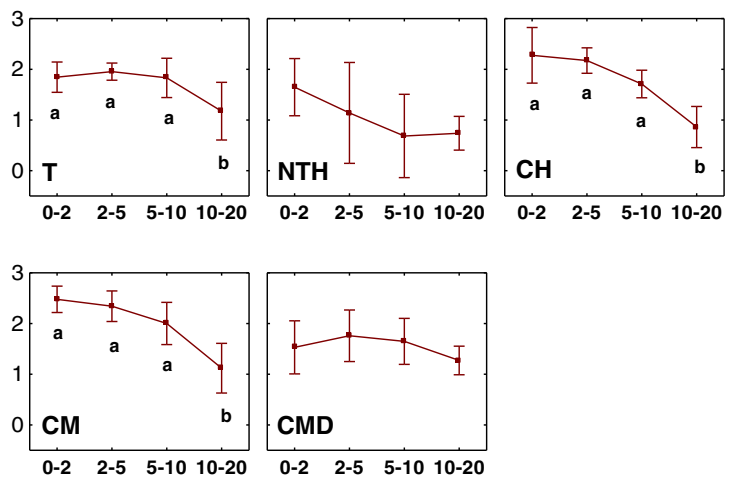

Fungivores
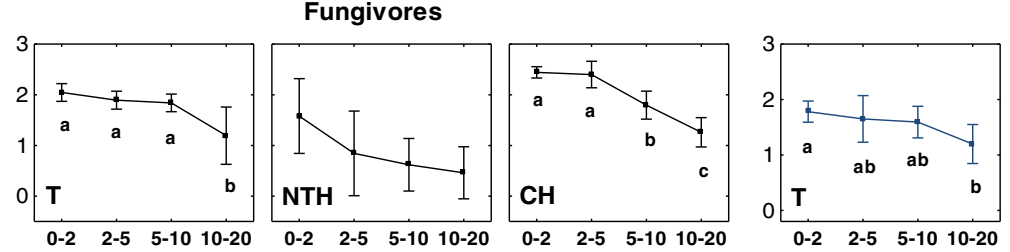

Herbivores
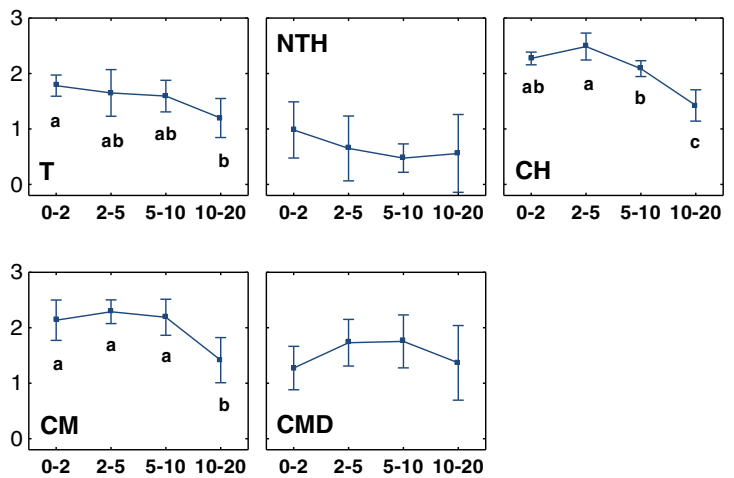

Omnivores
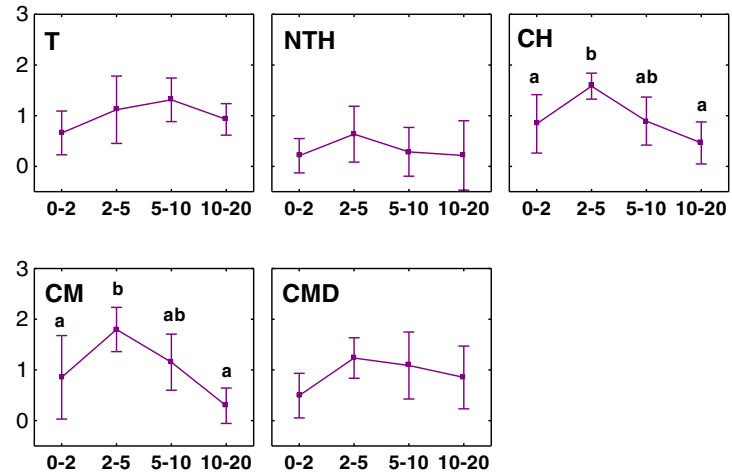

Fig. 2 Mean abundances of all nematodes, bacterivores, fungivores, herbivores, omnivores and predators (in $100 \mathrm{~g}$ of dry soil) across soil treatments at four soil depths $(0-2 \mathrm{~cm}, 2-6 \mathrm{~cm}, 6-10 \mathrm{~cm}, 10-20 \mathrm{~cm}) . T$ tillage, $N T H$ no tillage+herbicide, $\mathrm{CH}$ cover crop+herbicide, $\mathrm{CM}$ cover

with covered crops and soils from the upper layer) (after Ferris et al. 2001).

While the soil food web was well structured in the oak woodlands, indicator of complex, mature and suppressive biota (Ferris et al. 2001), soil food web condition was degraded or disturbed in olive groves. Degraded food webs are characterized by low fertility and low suppressiveness, as main services provided by organisms in the lower and upper guilds of the food web, while disturbed webs present low fertility but higher complexity (Ferris et al. 2001). The worst soil food web condition was found in the bare soil experimental treatment,
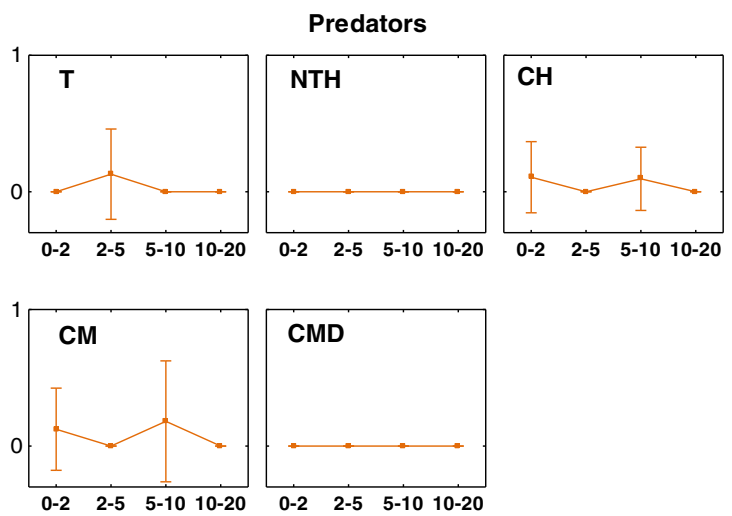

crop + mowing, CMD cover crop + mowing + disk harrow. Different letters below/over SE bars indicate significant differences at $p<0.05$ according to the Tukey test. Nematode abundances were log-transformed before analyses

confirming the strong effects of the absence of vegetation on the olive grove's soil food web. As could be expected, the soil food web was enriched in the upper soil layers, while no differences were found among the other soil depths.

As it has been previously reported by Minoshima et al. (2007), our results show a general decrease of nematode abundance with increased soil depth. Effects of tillage on nematodes are sometimes idiosyncratic, e.g. stimulating bacterial-feeding nematodes (Sánchez-Moreno et al. 2006) and affecting differently at varying soil depths (Van Capelle et al. 2012). In this sense, soil tillage may present unclear 
effects on nematodes; in previous studies, less than $5 \%$ of the variability of nematode taxa abundances was explained by the tillage practice in experimental conditions (Zhang et al. 2012), while up to $84 \%$ of arthropod abundance and diversity may be explained by tillage (Greenwood et al. 2011). In some cases, the intensity of tillage operation has been directly correlated to the abundances of plant-parasitic nematodes as those belonging to the genus Heterodera (Westphal et al. 2009). Our results from study area 2 show that total nematode abundance, abundance of bacterivores, fungivores and herbivores, was significantly reduced at $10-20-\mathrm{cm}$ depth in three of the treatments, irrespectively of the tillage regime.

3.3 Relationships between site features, soil properties and ecological indices

The canonical analysis relating ecological indices and site features extracted 20 and $18 \%$ of the variability of these site feature variables (roots 1 and 2, respectively) and 18 and $16 \%$ of the variability of the indices (roots 1 and 2, respectively). Ordination of variables along root 1 shows a positive association between higher latitudes and soils undisturbed by agricultural practices with nematode abundance and Structure Index values (Fig. 3). Longitude, altitude and solar radiation were the main determinants of root 2 , which scored oppositely to the Basal Index, the Channel Index, and the Enrichment Index.

The second canonical analysis related ecological indices and soil properties and management and extracted 19 and $12 \%$ of the variability of ecological indices (roots 1 and 2, respectively) and 16 and $10 \%$ of the variability of soil properties and management variables (roots 1 and 2 respectively). Root 1 was mainly defined by soil organic $\mathrm{C}$, low soil depth and low bulk density, followed by high cation exchange capacity and $\mathrm{N}$ (Fig. 3), and was associated to nematode abundance and the Enrichment Index. The second root was mainly defined by the absence of herbicides, and high $\mathrm{P}$, and was associated with the Maturity Index, the Structure Index and the Channel Index.

In previous studies, we found that site feature properties were associated to the nematode community as closely as soil properties, and elevation and slope displayed a good indicator value of soil disturbance mediated by human intervention (Sánchez-Moreno et al. 2011). The presence of such geographical patterns has recently been found for nematodes at larger spatial scales (Porazinska et al. 2012). In this study, the associations inferred by canonical analysis showed that native soils, present at higher latitudes, were associated to nematode abundance, nematode richness and food web complexity. Nematode diversity, higher in the natural areas, was associated to northern orientations, irrespectively of soil use. Opposite in previous reports (Sánchez-Moreno et al. 2011), slope was not a main determinant of nematode diversity. Our results indicate, in general, that the influence detected by site feature
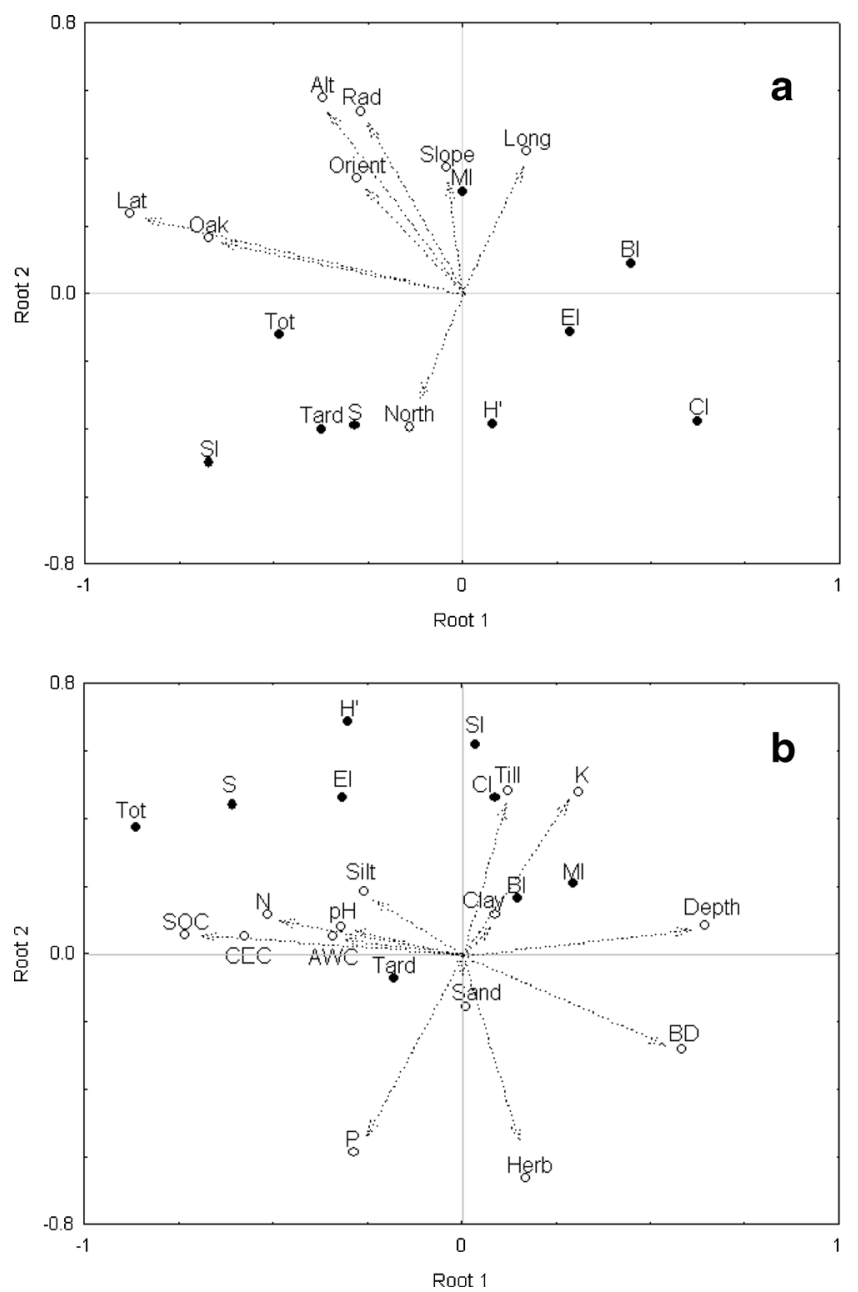

Fig. 3 Ordination resulting from two canonical analyses relating ecological indices to site feature variables (a) and soil properties (b). Tot. nematode abundance (number of nematodes $/ 100 \mathrm{~g}$ of dry soil), $S$ nematode taxa richness, $H^{\prime}$ Shannon Diversity Index, $M I$ Maturity Index, EI Enrichment Index, SI Structure Index, CI Channel Index, BI Basal Index, Tard. tardigrade abundance (number of tardigrades $/ \mathrm{kg}$ of dry soil), SOC soil organic carbon (\%), $N$ total nitrogen content, $E C$ electrical conductivity, SM soil moisture, Lat latitude, Long longitude, Alt altitude, Rad annual solar radiation, Slope slope, Orient orientation, Oak woodland soils, North \% north facing, BD bulk density, Herb herbicide use, Till tillage, $C E C$ cation exchange capacity, $A W C$ available water capacity

variables on ecological descriptors was mainly mediated by soil use. Commonly, nematodes are more abundant in upper soil layers (Scharroba et al. 2012), and, together with soil depth, the use of herbicides negatively affected nematode diversity and abundance, which were associated to higher soil $\mathrm{N}$ and $\mathrm{C}$, strongly depleted in vegetation-free experimental treatments.

\section{Conclusion}

Our results confirm the large effect of vegetation on soil biota. Nematode abundances and diversity presented lower values in 
bare soils treated with herbicides, intermediate values in nonherbicide areas and higher values at oak woodlands. Besides, treatments combining tillage and herbicide use, which maintained the soil free of vegetation, were the most disturbing in terms of the ecological descriptors of the nematode community and the soil food web. These effects primarily affected the lower levels of the soil food web and depleted both bacterialand fungal-mediated decomposition channels and then spread up through the soil food web reaching both microbivore guild and predator and omnivore guilds in the upper levels of the soil food web. The effects of site feature variables on the soil biota were mediated by soil use and management. In addition, although the effects of soil depth on soil organisms are often mediated by the effects of tillage, our results showed that nematode abundance decreased with soil depth, irrespectively of the tillage regime. Thus, based on our findings, we conclude that the traditional soil-management systems affected negatively on soil biodiversity as well as on soil properties. A minimum soil disturbance combined with plant covers could be at least partially offset this impact by providing a viable option to conserve soil quality and biodiversity with opportunities to increase overall land productivity as well as sustainable agro-environmental measures.

Acknowledgments We thank Luis Jiménez Meneses for his assistance during soil sampling. This work was financially supported by INIA (National Institute for Agricultural and Food Research and Technology), MAPA (Ministerio de Agricultura, Pesca y Alimentación) and the European Union through projects AEG-08-005, RTA2007-00010-C03-03, RTA2011-00007-00-00 and FEDER funding.

\section{References}

Barker KR (1985) Nematode extraction and bioassays. In: Barker KR, Carter CC, Sasser JN (eds) An advanced treatise on Meloidogyne, Vol 2 methodology. North Carolina State University Graphics, Raleigh, pp 19-35

Bongers T (1990) The maturity index: an ecological measure of environmental disturbance based on nematode species composition. Oecologia 83:14-19. doi:10.1007/BF00324627

Bongers T, Bongers M (1998) Functional diversity of nematodes. Appl Soil Ecol 10:239-251. doi:10.1016/S0929-1393(98)00123-1

Castillo P, Nico AI, Navas-Cortés JA, Landa BB, Jiménez DRM, Vovlas N (2010) Plant parasitic nematodes attacking olive trees and their management. Plant Dis 94:148-162. doi:10.1094/PDIS-94-2-0148

Castro J, Campos P, Pastor M (1996) Influencia de los sistemas de cultivo empleados en olivar y girasol sobre la composición de la fauna de artrópodos en el suelo. Bol Sanid Veg Plagas 22:557-570

Durán ZVH, Rodríguez PCR, Francia MJR, Martínez RA, Arroyo PL, Cárceles RB (2008) Benefits of plant strips for sustainable mountain agriculture. Agron Sustain Dev 28:497-505. doi:10.1051/ agro:2008020

Durán ZVH, Rodríguez CR, Arroyo PL, Francia MJR, Carceles RB (2009) Soil conservation measures in rainfed olive orchards in south-eastern Spain: impact of plant strips on soil water dynamics. Pedosphere 4:453-464. doi:10.1016/S1002-0160(09)60138-7
Durán ZVH, Francia MJR, García TI, Cuadros TS (2013) Implications of land cover types for soil erosion on semiarid mountain slopes: towards sustainable land use in problematic landscapes. Acta Ecol Sin 33:272-281. doi:10.1016/j.chnaes.2013.07.007

European Commission (2002) The olive oil sector in the European Union. Publication KF-44-02-084-EN-D. European Commission (Directorate-General for Agriculture), Brussels

European Commission (2010) Soil biodiversity: functions, threats and tools for policy makers. European Union Technical Report 2010049. European Commission (Directorate General Environment), Brussels

Ferris H (2010) Form and function: metabolic footprints of nematodes in the soil food web. Eur J Soil Biol 46:97-104. doi:10.1016/j.ejsobi. 2010.01.003

Ferris H, Bongers T, de Goede RGM (2001) A framework for soil food web diagnostics: extension of the nematode faunal analysis concept. Appl Soil Ecol 18:13-29. doi:10.1016/S0929-1393(01)00152-4

Ferris H, Venette RC, Scow KM (2004) Soil management to enhance bacterivore and fungivore nematode populations and their nitrogen mineralisation function. Appl Soil Ecol 25:19-35. doi:10.1016/j. apsoil.2003.07.001

García-Ruiz R, Ochoa V, Viñegla B, Hinojosa MB, Peña SR, Liébanas G, Linares JC, Carreira JA (2009) Soil enzymes, nematode community and selected physico-chemical properties as soil quality indicators in organic and conventional olive oil farming: influence of seasonality and site features. Appl Soil Ecol 41:305-314. doi:10.1016/j.apsoil. 2008.12.004

Gómez-Limón JA, Picazo TAJ, Reig ME (2012) Eco-efficiency assessment of olive farms in Andalusia. Land Use Policy 29:395-406. doi: 10.1016/j.landusepol.2011.08.004

Greenwood CM, Barbercheck ME, Brownie C (2011) Short term response of soil microinvertebrates to application of entomopathogenic nematode-infected insects in two tillage systems. Pedobiologia 54:177-186. doi:10.1016/j.pedobi.2011.02.003

MAGRAMA (2012) Encuesta sobre superficies y rendimientos de cultivos. Ministerio de Agricultura, Alimentación y Medio Ambiente, Madrid

MAPA (1994) Métodos oficiales de análisis Vol III: Suelos y aguas. Ministerio de Agricultura, Pesca y Alimentación, Madrid, Spain

Minoshima H, Jackson LE, Cavagnaro TR, Sánchez-Moreno S, Ferris H, Temple SR, Goyal S, Mitchell JP (2007) Soil food web and carbon dynamics in response to conservation tillage in California. Soil Sci Soc Am J 7:952-963. doi:10.2136/sssaj2006.0174

Montes-Borrego M, Navas-Cortés JA, Landa BB (2013) Linking microbial functional diversity of olive rhizosphere soil to management systems in commercial orchards in southern Spain. Agric Ecosyst Environ 181:169-178. doi:10.1016/j.agee.2013.09.021

Moreno B, Garcia RS, Cañizares R, Castro J, Benítez E (2009) Rainfed olive farming in south-eastern Spain: long-term effect of soil management on biological indicators of soil quality. Agric Ecosyst Environ 131:333-339. doi:10.1016/j.agee.2009.02.011

Neher DA, Campbell CL (1994) Nematode communities and microbial biomass in soils with annual and perennial crops. Appl Soil Ecol 1: $17-28$

Nekhay O, Arriaza M, Guzmán AJR (2009) Spatial analysis of the suitability of olive plantations for wildlife habitat restoration. Comput Electron Agric 65:49-64. doi:10.1016/j.compag.2008.07. 012

Nieto OM, Castro J, Fernández E (2012) Sustainable agricultural practices for Mediterranean olive groves. The effect of soil management on soil properties. Span J Soil Sci 2:70-77. doi:10.3232/sjss.2012. v2.n1.05

Parfitt RL, Yeates GW, Ross DJ, Schon NL, Mackay AD, Wardle DA (2010) Effect of fertilizer, herbicide and grazing management of pastures on plant and soil communities. Appl Soil Ecol 45:175186. doi:10.1016/j.apsoil.2010.03.010 
Porazinska DL, Giblin DRM, Powers TO, Thomas WK (2012) Nematode spatial and ecological patterns from tropical and temperate rainforests. PLoS One 7(9):e44641. doi:10.1371/journal.pone. 0044641

Sánchez-Moreno S, Minoshima H, Ferris H, Jackson LE (2006) Linking soil properties and nematode community composition: effects of soil management on soil food webs. Nematology 8:703-715. doi:10. $1163 / 156854106778877857$

Sánchez-Moreno S, Ferris H, Young MA, Culman SW, Jackson LE (2011) Abundance, diversity and connectance of soil food web channels along environmental gradients in an agricultural landscape. Soil Biol Biochem 43:2374-2383. doi:10.1016/j.soilbio.2011.07.016

Santos MJG, Morgado R, Ferreira NGC, Soares AMVM, Loureiro S (2011) Evaluation of the joint effect of glyphosate and dimethoate using a small-scale terrestrial ecosystem. Ecotoxicol Environ Safe 74:1994-2001. doi:10.1016/j.ecoenv.2011.06.003

Scharroba A, Dibbern D, Hünninghaus M, Kramer S, Moll J, Butenschoen O, Bonkowski M, Buscot F, Kandeler E, Koller R, Krüger D, Lueders T, Scheu S, Ruess L (2012) Effects of resource availability and quality on the structure of the micro-food web of an arable soil across depth. Soil Biol Biochem 50:1-11. doi:10.1016/j. soilbio.2012.03.002

Shannon CE (1948) A mathematical theory of communication. Bell Syst Tech J 27:379-423

Van Capelle C, Schrader S, Brunotte J (2012) Tillage-induced changes in the functional diversity of soil biota - a review with a focus on German data. Eur J Soil Biol 50:165-181. doi:10.1016/j.ejsobi. 2012.02.005

Westphal A, Xing LJ, Pillsbury R, Vyn TJ (2009) Effect of tillage intensity on population densities of Heterodera glycines in intensive soybean production systems. Field Crop Res 113:218-226. doi:10. 1016/j.fcr.2009.05.009

Yeates GW, Bongers T (1999) Nematode diversity in agroecosystems. Agric Ecosyst Environ 74:113-135. doi:10.1016/S0167-8809(99) 00033-X

Zhang X, Li Q, Zhu A, Liang W, Zhang J, Steinberger Y (2012) Effects of tillage and residue management on soil nematode communities in North China. Ecol Indic 13:75-81. doi:10.1016/j.ecolind.2011.05.009 